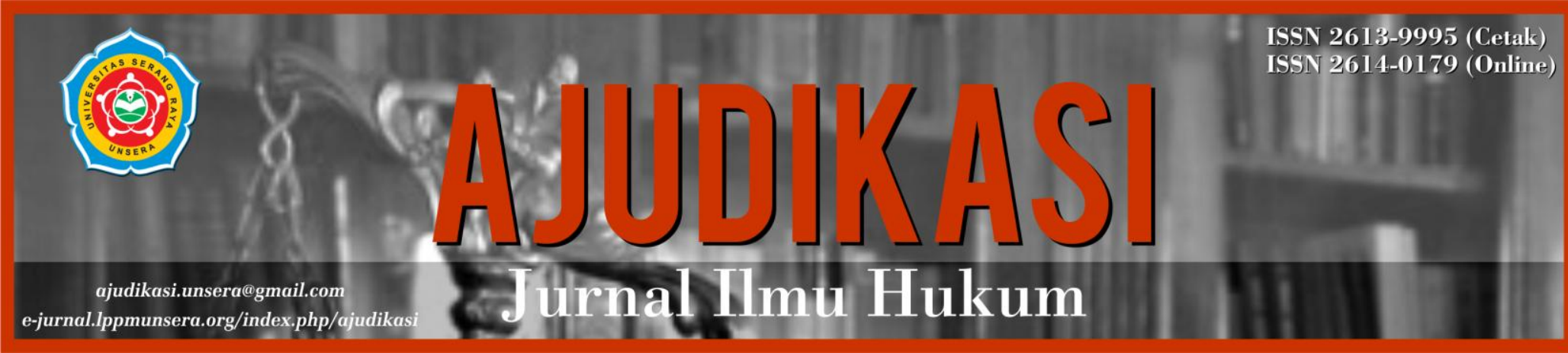

\title{
PENERAPAN ASAS HUKUM DALAM PEMBENTUKAN PERATURAN PERUNDANG-UNDANGAN
}

\author{
${ }^{1}$ Rokilah, ${ }^{2}$ Sulasno \\ Fakultas Ilmu Sosial, Ilmu Politik dan Ilmu Hukum, Universitas Serang Raya, Kota Serang, Banten. \\ Correspondent email : ilameidyfaihaazis@gmail.com
}

$\begin{array}{lll}\mid \text { Article History } & : & \\ \mid \text { | Submission } & : & \text { 16 Oktober 2021 } \\ \text { | Last Revissions } & : & \text { 27 Desember 2021 } \\ \text { | Accepted } & : & \text { 27 Desember 2021 } \\ \text { | Copyedits Approved } & : & \text { 28 Desember 2021 }\end{array}$

\begin{abstract}
Legal norms (legal norms, rechtnormen) actually regulate internal personal life (internal life) in a civilized and humanistic manner and also regulate interpersonal relationships in social processes. Legal principles can be in the form of a legal norm that is high in location and many things depend on it and the principle can just a norm. This study aims to determine the application of legal principles in statutory regulations; and to find out the application of other principles in the field of laws and regulations. The research method uses a qualitative normative juridical research method with data collection sourced from library research. Based on the nature of this research, it is an explanatory research, namely research that explains and strengthens a theory on the results of existing research. The results of the study show that legal principles are not concrete legal rules, but are the background of concrete and general or abstract regulations. In general, legal principles are not stated in the form of concrete regulations or in the form of articles, but the law cannot be understood without these principles and the application of other principles in accordance with the legal field of the relevant legislation, including: in criminal law, for example the principle of legality, the principle of presumption of innocence and in civil law, for example in contract law, among others: the principle of agreement, freedom of contract, and good faith
\end{abstract}

Keywords: Implementations; Legal Principles; Legislations; 


\section{A. PENDAHULUAN}

Dalam kehidupan manusia baik dalam proses pergaulan hidup bermasyarakat maupun sebagai pribadi yang beradab selalu membutuhkan norma. Kehidupan masyarakat senantiasa dipengaruhi oleh berbagai macam norma yang ada. Di Indonesia dikenal ada beberapa norma, antara lain norma agama, norma kesusilaan, norma kesopanan, dan norma hukum. Melalui ketaatan manusia atas norma akan dapat menjamin adanya tata tertib dalam kehidupannya sebagai makhluk sosial. Hal ini tidak terlepas dari fungsi norma itu sendiri sebagai patokan atau ukuran bagi kehidupan manusia dalam berperilaku atau bertindak dalam hidupnya. Sifat norma hukum dalam peraturan perundang-undangan dapat berupa: perintah (gebod); larangan (verbod); pengizinan (toestemming); dan pembebasan (vrijstelling). Di dalam peraturan perundangundangan terdapat tradisi yang hendak membatasi berlakunya norma hanya bagi mereka yang tidak termasuk dalam organisasi pemerintahan. Norma hanya ditujukan kepada rakyat, baik dalam hubungan antar sesamanya maupun antara rakyat dan pemerintah. Norma yang mengatur hubungan antar bagian-bagian organisasi pemerintahan dianggap bukan norna yang sebenarnaya, dan hanya dianggap norma organisasi. Oleh karena itu, norma hukum dalam peraturan perundang-undangan selalu berlaku ke luar. Norma hukum umum ditujukan kepada orang banyak bukan orang tertentu. Berdasarkan ketiga unsur norma tersebut, terdapat kombinasi norma yang umum-abstrak, umum-konkret, individual-abstrak, dan individual-konkret. Sebuah norma, termasuk norma hukum mengandung unsur-unsur berikut: a) cara keharusan berperilaku (operator norma); b) seorang atau sekelompok orang (subyek norma); c) perilaku yang dirumuskan (obyek norma); dan d) syarat-syaratnya (kondisi norma). ${ }^{1}$

Berbeda dengan norma-norma yang lainnya, norma hukum (legal norm, rechtnormen) mengatur secara nyata internal kehidupan pribadi (internal life) dalam berperadaban dan humanis dan juga mengatur hubungan antarpribadi dalam proses sosial, baik secara langsung maupun tidak langsung. Sebab norma hukum ditujukan untuk kebahagiaan pribadi sekaligus kedamaian hidup bersama, baik melalui keamanan dan ketertiban maupun dalam memperbaharui perilaku. ${ }^{2}$ Menurut Logemann, setiap peraturan hukum pada hakikatnya dipengaruhi oleh 2 (dua) unsur penting, yaitu: pertama: unsur riil, karena sifatnya yang konkret, bersumber dari lingkungan tempat manusia hidup, kedua: unsur idiil, karena sifatnya yang abstrak, bersumber pada diri manusia itu sendiri yang berupa akal/pikiran dan perasaan. Unsur-unsur yang mempengaruhi peraturan perundang-undangan ini, sesungguhnya lebih tepat disebut asas. Oleh karena itu, bangunan yang bersumber pada perasaan manusia disebut asas-asas (beginselen),

1 Maria Farida Indrati S, 2007, Ilmu Perundang-undangan I: Jenis, Fungsi, dan Materi Muatan, Yogyakarta, Kanisius, hlm. 35-37.

2 I Gde Pantja Astawa dan Suprin Na'a, 2012, Dinamika Hukum dan Ilmu Perundang-undangan di Indonesia, Bandung, Alumi, hlm . 25. 
sedangkan yang bersumber pada akal pikiran manusia disebut pengertian-pengertian (begrippen). ${ }^{3}$

Suatu noma/aturan hukum (rechtsregel) memiliki isi yang jauh lebih konkret, yang dapat diterapkan secara langsung. Berbeda dengan asas hukum yang daya kerjanya secara tidak langsung (indirect werking), yakni menjalankan pengaruh pada interpretasi terhadap aturan hukum. Norma/aturan hukum tidak hanya memiliki isi yang lebih konkret dan dapat diterapkan secara langsung, tetapi lebih dari itu aturan hukum itu juga bersifat "semua atau tidak sama sekali" (alles of niets karakter). Berbeda dengan asas hukum yang tidak memilik sifat "semua atau tidak sama sekali". Seringkali terhadap kejadian yang sama dapat diterapkan berbagai asas hukum, yang sesuai dengan peranan pada interpretasi aturan-aturan yang dapat diterapkan. Dalam hal itu maka harus dipertimbangkan asas hukum yang mana yang paling relevan. ${ }^{4}$

Pada landasan suatu sistem kaidah hukum terdapat kaidah yang fundamental, yakni asas-asas hukum. Menurut Paul Scholten, asas adalah pikiran-pikiran dasar, yang terdapat di dalam dan di belakang sistem hukum masing-masing yang dirumuskan dalam aturan-aturan perundang-undangan dan putusan-putusan hakim. ${ }^{5}$ Sedangkan asas hukum adalah kecenderungan yang diisyaratkan oleh pandangan kesusilaan kita pada hukum dan merupakan sifat-sifat umum dengan keterbatasannya sebagai pembawaan yang umum itu tetapi harus ada. Asas hukum dapat berupa suatu norma hukum yang tinggi letaknya dan banyak hal yang tergantung kepadanya serta asas dapat berupa sebuah norma saja.

Sementara itu, dalam hukum positif Indonesia terdapat ketentuan dalam Undangundang Nomor 12 Tahun 2011 tentang Pembentukan Peraturan Perundang-undangan, yang membedakan 'asas pembentukan peraturan perundang-undangan' dan 'asas materi muatan peraturan perundang-undangan. 'Asas' pembentukan peraturan perundangundangan' yang diatur dalam Pasal 5 Undang-undang 12 Tahun 2011 dapat disebut syarat-syarat prosedural atau asas-asas hukum formal. Dalam membentuk Peraturan Perundang-undangan harus dilakukan berdasarkan pada asas Pembentukan Peraturan Perundang-undangan yang baik, yang meliputi: a). kejelasan tujuan; b). kelembagaan atau pejabat pembentuk yang tepat; c). kesesuaian antara jenis, hierarki, dan materi muatan; d). dapat dilaksanakan; e). kedayagunaan dan kehasilgunaan; f). kejelasan rumusan; dan g). keterbukaan.

Sedangkan asas 'materi muatan peraturan perundang-undangan' yang diatur dalam Pasal 6 Undang-undang Nomor 12 Tahun 2011 merupakan syarat-syarat substansil atau asas-asas hukum material dalam pembentukan peraturan perundang-undangan. Materi muatan Peraturan Perundang-undangan harus mencerminkan asas: a). pengayoman; b). kemanusiaan; c). kebangsaan; d). kekeluargaan; e). kenusantaraan; f). bhinneka tunggal ika; g). keadilan; h). kesamaan kedudukan dalam hukum dan

Ibid., hlm . 81-82.

4 Dedy Triyanto Ari Rahmad, I Gusti Ngurah Wairocana, Ni Gusti Ayu Dyah Satyawati, Hubungan Antara Norma Hukum Dengan Asas Hukum, dalam Jurnal Kertha Negara : Journal Ilmu Hukum Vol. 01, No. 05, Juli 2013, hlm. 4.

5 Ibid., hlm. 2 . 
pemerintahan; i). ketertiban dan kepastian hukum; dan/atau j). keseimbangan, keserasian, dan keselarasan. Dalam ketentuan Pasal 5 dan Pasal 6 Undang-undang Nomor 12 Tahun mengatur tentang jenis asas yakni asas pembentukan peraturan perundang-undangan dan asas materi muatan peraturan perundang-undangan, kedua pasal tersebut dalam pembentuk undang-undang telah menjadikan asas hukum secara langsung sebagai rumusan norma/aturan hukum. Walaupun hal tersebut merupakan penegasan akan arti pentingnya asas hukum sebagai landasan pertimbangan pembentukan peraturan perundang-undangan, namun hal tersebut tidak dibenarkan secara teori. Asas hukum tidak dapat digunakan secara langsung sebagai rumusan pasal-pasal yang ada dalam suatu peraturan perundang-undangan, melainkan melandasi dan/atau melatarbelakangi rumusan pasal-pasal tersebut.

Asas-asas peraturan perundang-undangan atau asas hukum dalam pembentukan peraturan perundang-undangan merupakan nilai-nilai yang dijadikan pedoman dalam penuangan norma atau isi peraturan kedalam bentuk dan susunan peraturan perundangundangan yang diinginkan, dengan penggunaan metode yang tepat dan mengikuti prosedur yang telah ditentukan. Selain itu, asas-asas hukum umum yang secara khusus dapat diterapkan juga pada pembentukan peraturan perundang-undangan antara lain asasasas: lex specialis derograt legi generali (undang-undang/peraturan perundang-undangan yang bersifat khusus mengenyampingkan undang-undang/peraturan perundang-undangan umum); lex posteriori derograt legi priori (undang-undang/peraturan perundangundangan yang dikeluarkan sesudahnya, mengenyampingkan undang-undang/peraturan perundang-undangan yang dikeluarkan sebelumnya); lex superiori derograt legi inferiori (peraturan perundang-undangan yang lebih tinggi mengenyampingkan peraturan perundang-undangan yang lebih rendah). Berdasarkan uraian masalah di atas maka dirumuskan masalah sebagai berikut: pertama; bagaimana penerapan asas hukum dalam pembentukan peraturan perundang-undangan dan, kedua; bagaimana pemberlakuan asas lain dalam bidang hukum peraturan perundang-undangan.

\section{B. METODE PENELITIAN}

Pada penelitian ini menggunakan metode penelitian yuridis normatif yang bersifat kualitatif yaitu penelitian yang mengacu pada norma hukum yang terdapat dalam peraturan perundang-undangan dan norma-norma yang hidup dan berkembang dalam masyarakat. Berdasarkan sifat penelitian ini yang menggunakan metode penelitian bersifat deskriptif analitis, analisis data yang dipergunakan adalah pendekatan kualitatif terhadap data primer dan data sekunder. ${ }^{6}$ Adapun sumber data dengan memanfaatkan data sekunder yang terdiri dari bahan hukum primer, bahan hukum sekunder dan bahan hukum tersier yang bersumber dari penelitian kepustakaan (library research) dengan menggunakan berbagai literatur berupa peraturan perundang-undangan, buku-buku, karya ilmiah berupa jurnal, artikel dan sumber lainnya yang berkaitan dengan permasalahan.

6 Zainuddin Ali, 2016, Metode Penelitian Hukum, Jakarta, Sinar Grafika, hlm. 105. 
Berdasarkan sudut sifat penelitian ini merupakan penelitian eksplanatoris, yakni penelitian yang menerangkan dan memperkuat suatu teori terhadap hasil-hasil penelitian yang ada. ${ }^{7}$ Menurut Hans Kelsen hukum termasuk dalam sistem norma yang dinamik (nomodynamics), oleh karena hukum itu selalu dibentuk dan dihapus oleh lembaga atau otoritas yang berwenang membentuk dan menghapusnya, sehingga dalam hal ini tidak dilihat dari segi isi dari norma tersebut, tetapi dilihat dari segi berlakunya atau pembentukannya. Norma itu valid apabila dibuat oleh lembaga atau otoritas yang berwenang membentuknya serta bersumber dan berdasar pada norma yang lebih tinggi, sehingga dalam hal ini norma yang lebih rendah (inferior) dapat dibentuk oleh norma yang lebih tinggi (superior), dan norma itu berjenjang-jenjang dan berlapis-lapis membentuk hierarki. ${ }^{8}$

\section{HASIL DAN PEMBAHASAN}

\section{Penerapan Asas Hukum dalam Pembentukan Peraturan Perundang-Undangan}

Umumnya dalam buku teks dan pembahasan asas-asas hukum dalam pembentukan perundang-undangan hanya syarat-syarat formal atau prosedural saja yang disebutkan, agar hukum yang sedang dan akan dibuat menjadi 'hukum yang baik dan patut'. Jarang sekali asas-asas hukum material atau substansial disebutkan agar menjadi 'hukum yang adil'. ${ }^{9}$ Mengenai asas hukum relevan dikemukakan pandangan Satjipto Rahardjo yang menyatakan bahwa asas hukum merupakan 'jantung-nya' peraturan hukum. Menurut Satjipto Rahardjo, asas hukum disebut jantungnya peraturan hukum karena dua alasan. Pertama, karena asas hukum merupakan landasan yang paling luas bagi lahirnya suatu peraturan hukum. Ini berarti peraturan-peraturan hukum itu pada akhirnya bisa dikembalikan kepada asas tersebut. Kedua, asas hukum juga merupakan ratio legis (alasan) bagi lahirnya peraturan hukum. Asas hukum ini tidak akan habis kekuatannya dan akan tetap saja ada dalam melahirkan berbagai peraturan hukum. Dari asas hukum dapat diturunkan peraturan-peraturan hukum. Sementara Soedikno Mertokusumo, mengatakan bahwa asas hukum bukan merupakan hukum konkret, melainkan merupakan pikiran dasar yang abstrak, atau merupakan latar belakang peraturan konkret yang terdapat dan di belakang setiap sistem hukum yang terjelma dalam peraturan perundang-undangan dan putusan hakim yang merupakan hukum positif dan dapat diketemukan dengan mencari sifat-sifat atau ciriciri yang umum dalam peraturan konkret tersebut. ${ }^{10}$

Selain itu Paul Scholten mengemukakan bahwa, sebuah asas hukum (rechtbeginsel) bukanlah sebuah aturan hukum (rechtsregel). Untuk dikatakan sebagai

Ishaq, 2017, Metode Penelitian Hukum Dan Penulisan Skripsi, Tesis, Serta Disertasi, Bandung, Alfabeta, hlm.20.

8 Maria Farida Indrati S, Op.Cit, hlm. 23.

9 Otong Rosadi, Hukum Kodrat, Pancasila Dan Asas Hukum Dalam Pembentukan Hukum Di Indonesia, dalam Jurnal Dinamika Hukum Vol 10, No 3 (2010) hlm. 285.

10 Putera Astomo, 2018, Ilmu Perundang-undangan: Teori dan Praktik di Indonesia, Depok, Rajawali Pers, hlm. 89 . 
aturan hukum, sebuah asas hukum adalah terlalu umum sehingga ia atau bukan apaapa atau bicara terlalu banyak (of niets of veel te veel zeide). Penerapan asas hukum secara langsung melalui jalan subsumsi atau pengelompokkan sebagai aturan tidaklah mungkin, karena itu terlebih dahulu perlu dibentuk isi yang lebih konkret. Dengan perkataan lain, asas hukum bukanlah hukum, namun hukum tidak dapat dimengerti tanpa asas-asas tersebut. Scholten mengemukakan lebih lanjut, adalah menjadi tugas ilmu pengetahuan hukum untuk menelusuri dan mencari asas hukum itu dalam hukum positif. $^{11}$

Pentingnya asas-asas hukum dalam pembentukan peraturan perundangundangan menurut Paul Scholten sebagaimana disitir oleh A. Hamid S. Attamimi, ialah untuk dapat melihat benang merah dari sistem hukum positif yang ditelusuri dan diteliti. Asas-asas hukum ini juga dapat dijadikan patokan bagi pembentuk peraturan perundang-undangan agar tidak melenceng dari cita hukum (rechtsidee) yang telah disepakati bersama. Namun, secara teoritikal asas-asas hukum bukanlah aturan hukum (rechtsregel), sebab asas-asas hukum tidak dapat diterapkan secara langsung terhadap suatu peristiwa konkret dengan menganggapnya sebagai bagian dari norma hukum. Meskipun demikian, asas-asas hukum tetap diperlukan dalam pembentukan peraturan perundang-undangan, sebab hukum tidak dapat dimengerti karena asas-asas hukum. Terkait dengan pentingnya asas hukum dalam pembentukan peraturan perundangundangan maka fungsi asas, antara lain: 1) sebagai patokan dalam pembentukan dan/atau pengujian norma hukum; 2) untuk memudahkan kedekatan pemahaan terhadap hukum; 3) sebagai cermin dari peradaban masyarakat atau bangsa dalam memandang perilaku. ${ }^{12}$

Asas hukum sebagai suatu sarana yang membuat hukum hidup, tumbuh dan berkembang. Dengan adanya asas hukum, menyebabkan hukum tidak sekedar kumpulan peraturan, karena asas itu mengandung nilai-nilai dan tuntutan-tuntutan etis. Sementara B. Arief Sidharta menyebut bahwa asas hukum lebih merupakan nilai, sebagai nilai maka fungsi asas hukum, adalah: (1) sebagai norma kritis untuk menilai kualitas dari aturan hukum yang seharusnya merupakan penjabaran nilai tersebut dan (2) sebagai sarana bantu untuk mengintepretasikan aturan yang bersangkutan yaitu untuk menetapkan ruang lingkup wilayah penerapan ketentuan undang-undang yang bersangkutan. ${ }^{13}$

Dalam praktik terdapat norma-norma hukum, yang tidak dapat ditelusuri bagaimana bunyinya asas yang mendasarinya. Salah satu contoh yang dapat dikemukakan, norma hukum positif dalam bidang lalu lintas, yang menyuruh pemakai jalan umum yang mempergunakan bagian kiri dari jalan itu. Untuk norma itu sulit dicarikan asasnya, tetapi kalau ia menjadi asas maka norma hukum itu sendirilah yang berfungsi sebagai asas. Selanjutnya Paton, mengatakan adanya norma hukum dapat

Maria Farida Indrati S, Op. Cit., hlm. 253.

I Gde Pantja Astawa dan Suprin Na'a, Op.Cit., hlm . 81-82.

Otong Rosadi, Op. Cit., hlm. 285. 
dikembalikan kepada suatu asas. Ia tak sanggup menyebutkan asas yang mendasari suatu norma hukum. Keadaan seperti itu menurut Mahadi, banyak terdapat pada bidang-bidang hukum yang netral, yaitu bidang-bidang hukum yang tidak ada kaitannya dengan agama dan kebudayaan. Sebaliknya dalam bidang-bidang hukum yang non-netral (bidang-bidang hukum yang erat kaitannya dengan agama dan budaya), dapat bertemu dengan norma hukum yang dapat dikembalikan kepada suatu asas. $^{14}$

Untuk menghindari pembentukan peraturan perundang-undangan yang memiliki kecenderungan memihak dan menguntungkan pihak/kelompok berkuasa, dan untuk menghindari pembentukan peraturan perundang-undangan yang represif dan mengancam kebebasan warga negara, serta untuk menjamin efektif berlakunya suatu undang-undang maka pembentuk undang-undang harus memerhatikan dan mempedomani prinsip-prinsip atau asas-asas tertentu dalam membentuk peraturan perundang-undangan. Abeer Bashier dan Eid Ahmad Al-Husban mengatakan bahwa The pub lic authority specalized in legislation must comply with a set of principle and criteria that constiutes a complete and integrated group designed for the enactment of legislation that are characteried with universality and intellectivity on the one hand, and on the other must comply with the higher and more supreme legislations in compromity with the principle of hierarchy of legal rules and the priciple of the supremacy of the law (otoritas publik yang mengkhususkan diri dalam pembentukan undang-undang harus mematuhi seperangkat prinsip dan kriteria yang merupakan suatu kelengkapan dan kelompok pemandu yang dirancang untuk pemberlakuan suatu undang-undang yang ditandai dengan universitalitas dan intelektual di satu sisi, dan di sisi lain harus sesuai dengan peraturan perundang-undangan yang lebih tinggi dan sesuai dengan prinsip hierarki aturan hukum dan prinsip supremasi hukum). ${ }^{15}$

Philipus M. Hadjon, mengemukakan bahwa fungsi asas-asas pembentukan peraturan perundang-undangan yang baik adalah sebagai dasar pengujian dalam pembentukan aturan hukum (uji formal) maupun sebagai dasar pengujian terhadap aturan hukum yang berlaku (uji materiil). Sementara Department of Legislative Services Office of Police Analysis Annapolis Maryland, mengatakan bahwa fungsi asas-asas pembentukan peraturan perundang-undangan adalah to ensure accuary, clarity, and uniformity in the drafting of legislation by promoting compliance with contitutional princple, rules of law and statutory interpretation, and accepted practices regarding style, form, and process (memastikan keakuratan, kejelasan, dan keseragaman dalam penyusunan undang-undang, mempromosikan kepatuhan terhadap prinsip-prinsip konstitusional, aturan hukum dan hukum interpretasi, dan praktik yang diterima tentang gaya, bentuk, dan proses). ${ }^{16}$

Sementara dalam konteks pembentukan hukum melalui peraturan perundangundangan dapat dikemukakan pandangan I.C. van der Vlies dalam "Het wetsbegrip en

Putera Astomo, Op. Cit., hlm. 88.

Ibid., hlm. 90-91.

Ibid., hlm. 95. 
beginselen van behoorlijke regelgeving" yang membagi asas-asas pembentukan peraturan negara yang baik menjadi: Asas-asas yang formal, meliputi: asas tujuan yang jelas (beginsel van duidelijke doelstelling); Asas organ/lembaga yang tepat (beginsel van het juiste orgaan); Asas perlunya pengaturan (het noodzakelijkheids beginsel); Asas dapatnya dilaksanakan (het beginsel van uitvoerbaarheid); dan Asas konsensus (het beginsel van de consesus). ${ }^{17}$

Adapun asas-asas pembentukan peraturan negara yang material meliputi: (1) Asas tentang terminologi dan sistematika yang benar (het beginsel van duidelijke terminologie en duidelijke sytematiek); (2) Asas tentang dapat dikenali (het beginsel van de kenbaarheid); (3) Asa perlakuan yang sama dalam hukum (het rechtsgelijkheids beginsel); (4) Asas kepastian hukum (het rechtszekerheids beginsel); dan (5) Asas pelaksanaan hukum sesuai keadaan individual (het beginsel van de individuele rechtsbedeling). Asas-asas material meliputi asas sesuai dengan cita hukum Indonesia dan norma fundamental negara, asas sesuai dengan hukum dasar negara, asas sesuai dengan prinsip-prinsip negara berdasar atas hukum dan asas sesuai dengan prinsip-prinsip pemerintahan berdasarkan sistem konstitusi. ${ }^{18}$

Dalam pembentukan peraturan perundang-undangan yang berlaku saat ini terdapat kecenderungan untuk meletakkan asas-asas hukum atau asas-asas pembentukan peraturan perundang-undangan tersebut di dalam pasal-pasal awal, atau dalam Bab Ketentuan Umum, seperti dirumuskan dalam Undang-undang Nomor 12 Tahun 2011 tentang Pembentukan Peraturan Perundang-undangan. Hal tersebut seperti dijelaskan pada latar belakang dimana dalam ketentuan Pasal 5 dan Pasal 6 asas hukum telah ditetapkan menjadi suatu rumusan norma hukum. Apabila hal tersebut dilakukan, maka hal itu tidak sesuai dengan pendapat Paul Scholten di atas yang menyatakan bahwa sebuah asas hukum (rechtbeginsel) bukanlah sebuah aturan hukum (rechtsregel). Untuk dikatakan sebagai aturan hukum, sebuah asas hukum adalah terlalu umum. Atau dengan perkataan lain bahwa peraturan perundang-undangan tersebut sudah menjadikan suatu asas hukum atau asas pembentukan peraturan perundang-undangan menjadi suatu norma hukum. Sebagai suatu norma hukum hal tersebut akan berakibat adanya suatu sanksi apabila asas-asas tersebut tidak dipenuhi atau tidak dilaksanakan. Oleh karena itu, dalam pembentukan peraturan perundangundangan tidak lagi menjadikan suatu asas hukum atau asas pembentukan peraturan perundang-undangan sebagai norma hukum dalam peraturan perundang-undangan yang akan dibentuk.

Otong Rosadi, Op.Cit., hlm. 285.

Ibid. 


\section{Pemberlakuan Asas Lain Dalam Bidang Hukum Peraturan Perundang- undangan}

Menurut The Liang Gie, bahwa asas adalah suatu dalil umum yang dinyatakan dalam istilah umum tanpa menyarankan cara khusus mengenai pelaksanaannya yang diterapkan pada serangkaian perbuatan untuk menjadi petunjuk yang tepat bagi perbuatan itu. Van Eikema Hommes, mengatakan bahwa asas hukum tidak boleh dianggap sebagai norma hukum konkret, tetapi perlu dipandang sebagai dasar umum atau petunjuk bagi hukum yang berlaku. pembentukan hukum praktis perlu berorientasi pada asas-asas hukum tersebut. Dengan kata lain, asas hukum adalah dasar atau petunjuk arah dalam pembentukan hukum positif. Belefroid berpendapat bahwa asas hukum adalah norma dasar yang dijabarkan dari hukum positif dan oleh ilmu hukum tidak dianggap berasal dari aturan-aturan yang lebih umum. Asas hukum ini merupakan pengendapan hukum positif dalam suatu masyarakat. ${ }^{19}$

Asas-asas pembentukan peraturan perundang-undangan adalah suatu pedoman atau suatu rambu-rambu dalam pembentukan peraturan perundang-undangan yang baik. Dalam bidang hukum yang menyangkut pembentukan peraturan perundangundangan negara, Burkhardt Krems menyebutkannya dengan istilah staatsliche Rechtssetzung, sehingga pembentukan peraturan itu menyangkut: 1) isi peraturan (inhalt der regelung); 2) bentuk dan susunan peraturan (for, der regelung); 3) metoda pembentukan peraturan (methode der ausarbeitung der regelung); 4) prosedur dan proses pembentukan peraturan (verfanren der ausarbeitung der regelung). Berdasarkan hal-hal tersebut di atas, maka asas bagi pembentukan peraturan perundang-undangan negara akan meliputi asas-asas hukum yang berkaitan dengan itu. $^{20}$

A. Hamid S. Attamimi mengemukakan bahwa pembentukan peraturan perundang-undangan Indonesia yang patut, adalah sebagai berikut: a) Cita Hukum Indonesia; b) Asas negara berdasar atas hukum dan asas pemerintahan berdasar sistem konstitusi; c) Asas-asas lainnya. Dengan demikian, asas-asas pembentukan peraturan perundang-undangan Indonesia yang patut akan mengikuti pedoman dan bimbingan yang diberikan oleh: a) Cita Hukum Indonesia yang tidak lain melainkan Pancasila (Sila-sila dalam hal tersebut berlaku sebagai Cita (Idee), yang berlaku sebagai "bintang pemandu"); b) Norma fundamental negara yang juga tidak lain melainkan Pancasila (Sila-sila dalam hal tersebut berlaku sebagai Norma); c) (1) Asas-asas negara berdasar atas hukum yang menempatkan undang-undang sebagai alaat pengaturan yang khas berada dalam keutamaan hukum (der primat des rechts); (2) Asas-asas pemerintahan berdasar sistem konstitusi yang menempatkan undang-undang sebagai dasar dan batas penyelenggaraan kegiatan-kegiatan pemerintahan. ${ }^{21}$

19 Putera Astomo, 2018, Op Cit., hlm. 88-89.

Maria Farida Indrati S, Op. Cit., hlm. 252-253.

21 Ibid., hlm. 254-255. 
Asas lain sesuai dengan bidang hukum peraturan perundang-undangan yang bersangkutan antara lain:

1. Dalam hukum pidana, misalnya, asas legalitas (legaliteit beginsel), asas tiada hukum tanpa kesalahan (geen straft zonder schuld), asas pembinaan narapidana, dan asas praduga tak bersalah (presumption of innocent);

2. Dalam hukum perdata, misalnya, dalam hukum perjanjian, antara lain; asas kesepakatan, kebebasan berkontrak, dan itikad baik.

Selain asas-asas pembentukan peraturan perundang-undangan yang baik sebagaimana diuraikan di atas, berlaku pula asas-asas antara lain: asas tata urutan/susunan (hierarki) peraturan perundang-undangan. Asas ini yang berasal dari teorinya Hans Kelsen dan Hans Nawiasky ini kemudian diadopsi secara tersirat ke dalam Pasal 7 ayat (1) dan (2) Undang-Undang Nomor 12 Tahun 2011 tentang Pembentukan Peraturan Perundang-undangan. Kekuatan hukum peraturan perundangundangan sesuai dengan hierarki sebagaimana dimaksud pada ayat (1). Dalam ketentuan ini yang dimaksud dengan "hierarki" adalah penjenjangan setiap jenis Peraturan Perundang-undangan yang didasarkan pada asas bahwa peraturan perundang-undangan yang lebih rendah tidak boleh bertentangan dengan peraturan perundang-undangan yang lebih tinggi. Asas ini diadopsi dari teorinya Hans Kelsen tentang jenjang norma hukum (Stufen Theory) yang kemudian dikembangkan oleh muridnya yaitu Hans Nawiasky (Theory van Stufenaufbau der Rechtsordnung). ${ }^{22}$

Sementara Purnadi Purbacaraka dan Soerjono Soekanto mengatakan bahwa ada 6 (enam) asas perundang-undangan, yakni antara lain: 1) undang-undang tidak berlaku surut; 2) undang-undang yang dibuat oleh penguasa yang lebih tinggi mempunyai kedudukan yang lebih tinggi pula (lex superiori derograt lex inferiori); 3) undang-undang yang bersifat khusus menyampingkan undang-undang yang bersifat umum (lex specialis derograt lex generalis); 4) undang-undang yang berlaku belakangan membatalkan undang-undang yang berlaku terdahulu (lex posteriori derograt lex priori); 5) undang-undang tidak dapat diganggu gugat; 6) undang-undang sebagai sarana untuk semaksimal mungkin dapat mencapai kesejahteraan spirituil dan materiil bagi masyarakat maupun individu, melalui pembaharuan atau pelestarian (asas welvaarstaat). ${ }^{23}$

Pandangan penulis bahwa dalam membentuk peraturan perundang-undangan harus dilakukan berdasarkan pada asas pembentukan peraturan perundang-undangan yang baik dan asas dalam materi muatan peraturan perundang-undangan, selain itu diperlukan asas yang disesuaikan dengan bidang hukum peraturan perundangundangan yang bersangkutan seperti dalam hukum pidana dan dalam hukum perdata, kemudian didukung juga dengan asas lain yang berkaitan dalam pembentukan peraturan perundang-undangan seperti asas hierarki, undang-undang tidak berlaku surut, undang-undang yang bersifat khusus menyampingkan undang-undang yang

Has Natabaya, Op.Cit., hlm.37-38.

${ }^{23}$ I Gde Pantja Astawa dan Suprin Na'a, Op.Cit., hlm . 84-85. 
bersifat umum (lex specialis derograt lex generalis); undang-undang yang baru menyampingkan undang-undang yang lama (lex posteriori derograt lex priori). Sehingga para pembentuk hukum itu harus menghadirkan tatanan hukum yang baik, dan tatanan hukum yang baik harus mendasarkan diri pada moral bangsa dimana hukum itu dibuat/disusun, bertumbuh dan berkembang. Moral bangsa itu lalu menjadi pemandu bagi asas-asas hukum yang menjadi dasar pembentukan peraturan perundang-undangan.

\section{KESIMPULAN}

Di dalam kehidupan masyarakat selalu terdapat berbagai macam norma yang secara langsung atau tidak langsung mempengaruhi tata cara seseorang untuk berperilaku atau bertindak. Pada umumnya asas hukum tidak dituangkan dalam bentuk peraturan konkret. Akan tetapi tidak jarang asas hukum itu dituangkan dalam peraturan konkret. Peraturan hukum yang konkret dapat diterapkan secara langsung pada peristiwanya, maka asas hukum diterapkan secara tidak langsung. Pada ketentuan Pasal 5 dan Pasal 6 Undang-undang Nomor 12 Tahun 2011, asas hukum telah ditetapkan menjadi suatu rumusan norma hukum, semestinya dalam pembentukan peraturan perundang-undangan tidak lagi menjadikan suatu asas hukum atau asas pembentukan peraturan perundangundangan sebagai norma hukum dalam peraturan perundang-undangan yang akan dibentuk. Ketika asas hukum atau asas pembentukan peraturan perundang-undangan dijadikan sebagai suatu norma hukum, hal tersebut akan berakibat adanya sanksi apabila asas-asas tersebut tidak dipenuhi atau tidak dilaksanakan.

Dalam pembentukan peraturan perundang-undangan terdapat asas-asas yang berlaku dalam peraturan perundang-undangan antara lain meliputi tiga bagian yaitu: pertama; asas-asas yang berkaitan dengan pembentukan peraturan perundang-undangan, kedua; asas-asas yang terkandung dalam materi muatan peraturan perundang-undangan, dan ketiga; asas lain sesuai dengan bidang hukum peraturan perundang-undangan yang bersangkutan hal demikian mencerminkan norma/aturan hukum yang terjelma dalam peraturan perundang-undangan tersebut.

\section{DAFTAR PUSTAKA}

\section{Buku}

Has Natabaya, Sistem Peraturan Perundang-undangan Indonesia, Jakarta: Konsitusi Press dan Tatanusa, 2008.

I Gde Pantja Astawa dan Suprin Na'a, Dinamika Hukum dan Ilmu Perundang-undangan di Indonesia, Bandung: Alumi, 2012.

Ishaq, Metode Penelitian Hukum Dan Penulisan Skripsi, Tesis, Serta Disertasi, Bandung: Alfabeta, 2017.

Maria Farida Indrati S, Ilmu Perundang-undangan I: Jenis, Fungsi, dan Materi Muatan, Yogyakarta: Kanisius, 2007.

Putera Astomo, Ilmu Perundang-undangan: Teori dan Praktik di Indonesia, Depok: Rajawali Pers: 2018.

Zainuddin Ali, Metode Penelitian Hukum, Jakarta: Sinar Grafika, 2016. 


\section{Jurnal}

Dedy Triyanto Ari Rahmad, I Gusti Ngurah Wairocana, Ni Gusti Ayu Dyah Satyawati, Hubungan Antara Norma Hukum Dengan Asas Hukum, Jurnal Kertha Negara: Journal Ilmu Hukum, Vol. 01, No. 05, Juli 2013.

Otong Rosadi, Hukum Kodrat, Pancasila Dan Asas Hukum Dalam Pembentukan Hukum Di Indonesia, Jurnal Dinamika Hukum, Vol 10, No 3 (2010).

\section{Peraturan Perundang-undangan}

Undang-Undang Republik Indonesia Nomor 12 Tahun 2011 Tentang Pembentukan Peraturan Perundang-Undangan (Lembaran Negara Republik Indonesia Tahun 2011 Nomor 82, Tambahan Lembaran Negara Republik Indonesia Nomor 5234) 